\title{
Lockdown and its Impact on Education, Environment and Economy
}

Swati Singh ${ }^{1 *}$, Meera Ranjith ${ }^{2}$

${ }^{1}$ Student Teacher, Mahatma Junior College of Education, Chembur, Mumbai-400071, India

${ }^{2}$ Assistant Professor, Mahatma Junior College of Education, Chembur, Mumbai-400071, India

DOI: $\underline{\text { 10.36348/jaep.2021.v05i04.005 }}$ | Received: 03.03.2021 | Accepted: 20.03 .2021 | Published: 29.04 .2021

*Corresponding author: Swati Singh

\section{Abstract}

The COVID-19 pandemic has not stopped at national borders. It has affected people regardless of nationality, level of education, income or gender. But the same has not been true for its consequences, which have hit the most vulnerable hardest. The paper reviews the (a) existing information on corona virus illness (b) policy responses and (c) its impact on the individuals, economic activities, and atmosphere of India. The pandemic has magnified a way of worry and insecurity among individuals because of probable job and pay loss. Consequently, existence of the many sectors and employability of a large range of staff is at stake. Despite the economic lag, the internment has become a boon for the atmosphere to revive because of less pollution and reduced discharge of effluents to water from factories. The policy formulators ought to think about this as wakeup decision and thereby align the individuals, economy, and atmosphere strategically.

Keywords: Covid-19, lockdown, Education, Economy, Environment.

Copyright ( $\odot 2021$ The Author(s): This is an open-access article distributed under the terms of the Creative Commons Attribution 4.0 International License (CC BY-NC 4.0) which permits unrestricted use, distribution, and reproduction in any medium for non-commercial use provided the original author and source are credited.

\section{INTRODUCTION}

Corona viruses (CoVs) are a group of viruses which affects human beings through zoonotic transmission. This is the third time in past two decades that novel virus has created pandemic condition, after Severe Acute Respiratory Syndrome (SARS) in 2003 and Middle East Respiratory syndrome corona virus (MERSCoV) in 2012 Pertaining to the Corona virus (2019), it was on December 31, 2019 wherein first case was reported to WHO Country Office in Wuhan, China with symptoms of unexplained low respiratory infections. This was classified as "pneumonia of unknown etiology" as the cause of infection was not known. On $12^{\text {th }}$ January 2020, WHO found that Corona virus was the reason of this infection in Wuhan and later on 11th February, WHO Director-General announced this novel $\mathrm{CoV}$ as 'COVID-19' which is an acronym of 'Corona virus disease 2019' [1]. Covid-19 contain a single-stranded RNA as nuclei material and are $65 \mathrm{~nm}-125 \mathrm{~nm}$ in diameter [2]. The major causes of concern for Covid-19 includes its global scale transmission, repeated emergence, significant number of deaths, infection and mortality to care providers and multiplicative effect in vulnerable or susceptible groups.

Covid-19 was declared pandemic disease by Director General-WHO on 11th March, he also briefed regarding the 13 -fold increase in positive cases in China and 114 countries suffering form 1, 18,000 positive cases and 4291 deaths till date [3]. In India the first confirmed positive case was reported on 30th January in a student from Thrissur district of Kerala who had returned home for a vacation from Wuhan University in China (India Today, 2020a) followed by two other cases on February 2 and 3 again in Kerala having the same history. As on 14th April, Ministry of Health \& Family Welfare (MOHFW) reported 10,815 positive cases and 358 deaths covering 32 states in India. Fig-1 shows the spread of COVID-19 from January 30, 2020 to April 14, 2020. It is evident from the figure that spread of corona virus became rapid after 15 March and started taking a horrible shape in entire country.

Subsequently Our PM Narendra Modi annouced a Lockdown from 25th March .Presently India has registered 6.84 million cases with 5.83 Million recovered and 106000 deaths.

\section{Impact on Economy}

The World Bank and rating agencies had initially revised India's growth for FY2021 with the lowest figures India has seen in three decades since India's economic liberalization in the 1990s. However, after the announcement of the economic package in mid-May, India's GDP estimates were downgraded even more to negative figures, signalling a deep 
recession. (The ratings of over 30 countries have been downgraded during this period.) On 26 May, CRISIL announced that this will perhaps be India's worst recession since independence. State Bank of India research estimates a contraction of over $40 \%$ in the GDP in Q1 The contraction will not be uniform, rather it will differ according to various parameters such as state and sector. On 1 September 2020, the Ministry of Statistics released the GDP figures for Q1 (April to June) FY21, which showed a contraction of $24 \%$ as compared to the same period the year before.

According to Nomura India Business Resumption Index economic activity fell from 82.9 on 22 March to 44.7 on 26 April. By 13 September 2020 economic activity was nearly back to pre-lockdown .Unemployment rose from $6.7 \%$ on 15 March to $26 \%$ on 19 April and then back down to pre-lockdown levels by mid-June. During the lockdown, an estimated 14 crore (140 million) people lost employment while salaries were cut for many others. More than $45 \%$ of households across the nation have reported an income drop as compared to the previous year. The Indian economy was expected to lose over $\square 32,000$ crore (US $\$ 4.5$ billion) every day during the first 21-days of complete lockdown, which was declared following the coronavirus outbreak. Under complete lockdown, less than a quarter of India's \$2.8 trillion economic movement was functional. Up to $53 \%$ of businesses in the country were projected to be significantly affected. Supply chains have been put under stress with the lockdown restrictions in place; initially, there was a lack of clarity in streamlining what an "essential" is and what is not. Those in the informal sectors and daily wage groups have been at the most risk. A large number of farmers around the country who grow perishables also faced uncertainty.

Major companies in India such as Larsen \& Toubro, Bharat Forge, UltraTech Cement, Grasim Industries, Aditya Birla Group, BHEL and Tata Motors have temporarily suspended or significantly reduced operations. Young startups have been impacted as funding has fallen. Fast-moving consumer goods companies in the country have significantly reduced operations and are focusing on essentials. Stock markets in India posted their worst loses in history on 23 March 2020. However, on 25 March, one day after a complete 21-day lockdown was announced by the Prime Minister, SENSEX and NIFTY posted their biggest gains in 11 years.

The Government of India announced a variety of measures to tackle the situation, from food security and extra funds for healthcare and for the states, to sector related incentives and tax deadline extensions. On 26 March a number of economic relief measures for the poor were announced totaling over 170,000 crore (US\$24 billion). The next day the Reserve Bank of India also announced a number of measures which would make available 374,000 crore (US $\$ 52$ billion) to the country's financial system. The World Bank and Asian Development Bank approved support to India to tackle the coronavirus pandemic.

The different phases of India's lockdown up to the "first unlock" on 1 June had varying degrees of the opening of the economy. On 17 April, the RBI Governor announced more measures to counter the economic impact of the pandemic including $\square 50,000$ crore (US\$7.0 billion) special finance to NABARD, SIDBI, and NHB. On 18 April, to protect Indian companies during the pandemic, the government changed India's foreign direct investment policy. The Department of Military Affairs put on hold all capital acquisitions for the beginning of the financial year. The Chief of Defence Staff has announced that India should minimize costly defense imports and give a chance to domestic production; also making sure not to "misrepresent operational requirements".

On 12 May the Prime Minister announced an overall economic package worth 20 lakh crore (US\$280 billion), $10 \%$ of India's GDP, with emphasis on India as a self-reliant nation. During the next five days the Finance Minister announced the details of the economic package. Two days later the Cabinet cleared a number of proposals in the economic package including a free food grains package. By 2 July 2020, a number of economic indicators showed signs of rebound and recovery. On 24 July the Finance Secretary of India said the economy is showing signs of recovery at a faster rate than anticipated, while the Economic Affairs Secretary said that he expects a v-shaped recovery for India. In July the Union Council of Ministers passed the National Educational Policy 2020 aimed at strengthening the economy.

\section{Impact on Environment}

The Covid-19 lockdown is healing the planet in a way never seen before in living history! Here are some of the most vital environmental changes seen in India after the Covid-19 lockdown:

\section{Improved Air Quality}

After the lockdown was put in place in many countries, there was lesser travelling done by people, whether it be by their own cars, or by trains and flights. Even industries were closed down and not allowed to function. This in turn led to the pollution in the air dropping significantly, as there was a marked decline in nitrous oxide emission. New Delhi was ranked as the most polluted city in the world by WHO in May 2014. The usual air quality of India's national capital according to the air quality index used to be 200 . When the pollution level hit its peak, the pollution level soared to 900 and sometimes, off the measurable scale. 
While 200 itself is 25 percent above unsafe level as deemed by World Health Organization, but as Delhi's 11 million registered cars were taken off the roads and factories and construction were ground to a halt, AQI levels have regularly fallen below 20. The skies are suddenly a rare, piercing blue. Even the birdsong seems louder. In the capital of New Delhi, government data shows the average concentration of PM 2.5 plunged by 71 percent in the space of a week -falling from 91 micrograms per cubic meter on March 20, to 26 on March 27, after the lockdown began.

\section{Impact on Water Quality}

Since there were no boats, whether they be fishing or pleasure ones, plying on the rivers and waterways, the water has cleared up. In areas like Venice, the water became so clear that the fish could be seen and there was better water flow. No doubt, because of the lesser human footfall even the oceans are recovering and marine life is thriving. The Uttarakhand Pollution Control Board Water from Har-ki-Pauri in Haridwar was tested and the results from the tests reveal that the water here has been classified as 'fit for drinking after chlorination', for the first time in decades.

According to a PCB scholar who is involved in the Clean Ganga project when asked about the rapid improvement in the water quality of Ganga water in Haridwar the source said that "the major pollutant of the river water was Industrial and Municipality wastewater."

It is assumed that due to the lockdown, the drainage of industrial waste into the river water has stopped and brought a significant change in the water quality.

\section{Effects on Wildlife}

Again where fish is concerned, the lockdown has seen a decline in fishing, which means that the fish biomass will increase after over-fishing almost depleted it. Apart from that, animals have been spotted moving about freely where once they would not dare to go. Even sea turtles have been spotted returning to areas they once avoided to lay their eggs, all due to the lack human interference.

As a result of the lockdown imposed due to Covid-19, tens of thousands of flamingos have gathered in the city of Navi Mumbai. The birds normally migrate to the area every year, but residents have reported that this year they have seen a massive increase in their numbers.

\section{Effect on Vegetation}

Plants are growing better because there is cleaner air and water, and because yet again there is no human interference. With everything at a standstill, plants are allowed to thrive and grow and produce more coverage and oxygen. Less litter also means lesser clogging of river systems, which is good in the long run for the environment.

In conclusion, though there has been a positive impact on the environment due to the lockdown, there is fear that once people start travelling again or go back to doing what they have been doing, all the positive impact will also disappear.

\section{Impact on Education}

There are both Positive and negative impact of Lockdown on education.

\section{Positive Impact}

Though the outbreak of COVID-19 has created many negative impacts on education, educational institutions of India have accepted the challenges and trying their best to provide seamless support services to the students during the pandemic. Indian education system got the opportunity for transformation from traditional system to a new era. The following points may be considered as the positive impact.

"Move towards Blended Learning: COVID-19 has accelerated adoption of digital technologies to deliver education. Educational institutions moved towards blended mode of learning. It encouraged all teachers and students to become more technology savvy. New ways of delivery and assessments of learning opened immense opportunities for a major transformation in the area of curriculum development and pedagogy. It also gives access to large pools of learners at a time.

Rise in use of Learning Management Systems: Use of learning management systems by educational institutions became a great demand. It opened a great opportunity for the companies those have been developing and strengthening learning management systems for use educational institutions [4].

Enhance the use of soft copy of learning material: In lockdown situation students were not able to collect the hard copies of study materials and hence most of the students used of soft copies materials for reference.

*Improvement in collaborative work- There is a new opportunity where collaborative teaching and learning can take on new forms. Collaborations can also happen among faculty/teachers across the world to benefit from each other.

*Rise in online meetings- The pandemic has created a massive rise in teleconferencing, virtual meetings, webinars and e-conferencing opportunities.

Enhanced Digital Literacy: The pandemic situation induced people to learn and use digital technology and resulted in increasing the digital literacy. 
Negative impact of COVID-19 on education

Education sector has suffered a lot due to the outbreak of COVID-19.

It has created many negative impacts on education and some of them are as pointed below:

Educational activity hampered: Classes have been suspended and exams at different levels postponed. Different boards have already postponed the annual examinations and entrance tests. Admission process got delayed. Due to continuity in lockdown, student suffered a loss of nearly 3 months of the full academic year of 2020-21 which is going to further deteriorate the situation of continuity in education and the as students would face much difficulty in resuming schooling again after a huge gap.

Impact on employment: Most of the recruitment got postponed due to COVID-19 Placements for students may also be affected with companies delaying the on board of students. Unemployment rate is expected to be increased due to this pandemic. In India, there is no recruitment in Govt. sector and fresh graduates fear withdrawal of their job offers from private sectors because of the current situation. The Centre for Monitoring Indian Economy's estimates on unemployment shot up from $8.4 \%$ in midMarch to $23 \%$ in early April and the urban unemployment rate to $30.9 \%$ (Educationasia.in). When the unemployment increases then the education gradually decreases as people struggle for food rather than education.

Unprepared teachers/students for online education- Not all teachers/students are good at it or at least not all of them were ready for this sudden transition from face to face learning to online learning. Most of the teachers are just conducting lectures on video platforms such as Zoom, Google meet etc. which may not be real online learning without any dedicated online learning platform.

Reduced global employment opportunitySome may lose their jobs from other countries and the pass out students may not get their job outside India due to restrictions caused by COVID-19. Many Indians might have returned home after losing their jobs overseas due to COVID-19. Hence, the fresh students who are likely to enter the job market shortly may face difficulty in getting suitable employment.
Many students who have already got jobs through campus interviews may not be able to join their jobs due to lockdown. The Indians who have been doing their jobs abroad may lose their jobs. Recent graduates in India are of also fearing for withdrawal of job offers from corporate sector.

\section{CONCLUSION}

COVID-19 has impacted immensely to the education sector of India. Though it has created many challenges, various opportunities are also evolved. The Indian Govt. and different stakeholders of education have explored the possibility of Open and Distance learning (ODL) by adopting different digital technologies to cope up with the present crisis of COVID-19. India is not fully equipped to make education reach all corners of the nation via digital platforms. The students who aren't privileged like the others will suffer due to the present choice of digital platforms. But universities and the government of India are relentlessly trying to come up with a solution to resolve this problem. The priority should be to utilize digital technology to create an advantageous position for millions of young students in India. It is need of the hour for the educational institutions to strengthen their knowledge and Information Technology infrastructure to be ready for facing COVID-19 like situations.

\section{REFERENCES}

1. Cascella, M., Rajnik, M., Cuomo, A., Dulebohn, S. C., \& Di Napoli, R. (2021). Features, evaluation, and treatment of coronavirus (COVID19). Statpearls [internet].

2. Shereen, M. A., Khan, S., Kazmi, A., Bashir, N., \& Siddique, R. (2020). COVID-19 infection: Origin, transmission, and characteristics of human coronaviruses. Journal of advanced research, 24, 91-98.

3. World Health Organization. (2020). Mental health and psychosocial considerations during the COVID-19 outbreak, 18 March 2020 (No. WHO/2019-nCoV/MentalHealth/2020.1). World Health Organization.

4. Misra, K. (2020). Covid-19: 4 negative impacts and 4 opportunities created for education. Retrieved on May 25, 2020 from https://www.indiatoday.in/educationtoday/feature philia/story/covid-19-4-negative-impactsand-4opportunities-created-for-education-1677206- 